\title{
Foreign Remittances, Banking Sector Development and Private Sector Investment
}

\author{
Peter Nderitu GITHAIGA*
}

Received: September 16, 2019 Revised: November 01, 2019 Accepted: January 05, 2020

\begin{abstract}
Purpose- This study seeks to investigate the impact of foreign remittances on private sector investment and the moderating role of banking sector development in Sub-Saharan African Countries. Research design, data, and methodology-The study has used a sample of 15 Sub-Saharan African countries and data for the years 1986 - 2017. Data was obtained from the World Bank Development Indicator (WDI) Database. Panel data diagnostic tests were conducted to ascertain the suitability of the data for regression analysis. The data was analyzed through descriptive and inferential statistics, while the hypothesis was tested through hierarchical regression analysis. Results- The finding of this study indicates that foreign remittances and banking sector development had a significant and positive effect on private investment in Sub-Saharan Africa. Besides, the banking sector development significantly moderated the foreign remittances and private sector investment relationship. Conclusions- Based on the results, the study concludes that banking sector development has an important influence on foreign remittances and private sector investment nexus. Due to the antagonistic interaction between foreign remittance and banking sector development, the study recommends the use of alternative ways of channeling remittances to private investment such as; issuance of diaspora bonds and appeal for direct investment by citizens living abroad.
\end{abstract}

Keywords: Foreign Remittances, Banking Sector Development, Private Sector Investment, Sub-Saharan Africa

JEL Classification: E22, F24, G21

\section{Introduction}

Remittances are compensatory transfers, either in the form of money or goods, which are transmitted to households back home by people working away from their communities of origin. These external capital inflows are perceived as having a compensatory effect for the human capital flight to the migrants' households, communities and the home countries at the macro-economic front (Randazzo \& Piracha, 2019; Inoue \& Hamori, 2016; Williams, 2018). According to World Bank (2019), there has been an unprecedented growth in remittances in the last three decades, where the documented amount of remittances increased from $\$ 68.6$ bn in 1990 to $\$ 689$ billion in 2018 ,

*Lecturer, Department of Accounting and Finance, Moi University, Kenya. Email nderitugithaiga@mu.ac.ke.

๑) Copyright: Korean Distribution Science Association (KODISA)

This is an Open Access article distributed under the terms of the Creative Commons Attribution NonCommercial License (https://creativecommons.org/licenses/by-nc/4.0/) which permits unrestricted noncommercial use, distribution, and reproduction in any medium, provided the original work is properly cited. with $\$ 529$ billion transferred to low- and middle-income countries. Moreover, studies show that the amount of documented remittances is twice as large as official aid and nearly two-thirds of foreign direct investment (FDI) flows to developing countries (Meyer \& Shera, 2017; Maïga et al., 2016). According to Ratha et al.(2016) remittances sent to developing countries translate to approximately $1.9 \%$ of their Gross Domestic Product (GDP). Escribà-Folch et al., (2018) and Meyer and Shera (2017) argue that remittances are the second-largest source of external development finance, after foreign direct investment, for developing economies. Moreover, in several countries; such as Tonga, Albania, Jordan, and Lesotho, remittances surpass all other forms of external capital inflows (Buch et al., 2002). Moreover, studies contend that remittances are an important external capital, as compared to official development assistance and foreign direct investment, due do its stability (Sinha et al., 2018; Azam et al., 2016).

Studies show that the flow of remittances is largely influenced by global migration patterns (Schiantarelli, 2005; 
Mckenzie, 2005). In Africa, unemployment, low wages and the threat of political instability and violence remain the key reasons for migration to developed countries (Poppe et al., 2016; Mberu \& Pongou, 2016; Khosa \& Kalitanyi, 2015). Further, cross-border migrations have been accelerated by advancements in transportation, communication, and regional integrations aimed at facilitating the smooth flow of people and goods across national frontiers. It estimated that by 2025 the number of documented migrants from Sub-Saharan Africa was 23.2 million which is likely to lead to loss of productivity; especially the flight of locally trained professionals whose expertise is vital for economic development (World Bank, 2019).

Given the importance attached to remittances, scholars have expended considerable effort to investigate the socioeconomic impact of these external capital flows. Extant literature demonstrates that remittances are mainly spent on consumption and unproductive investments, such as jewelry, which have no substantial impact on economic development (Petracou et al., 2017; Kuntsevych, 2016; Chami et al., 2018). This assertion is corroborated by the study of Adams et al. (2008) on a sample of 3,884 remittances received by households in Ghana, which found that there was no significant differences between the consumption and investment behaviors of the remittances receiving households and non-receiving ones. Despite the predominant view that remittances are mainly meant for consumption, some studies show that remittances have an impact on both social and economic dimension: education (Edward \& Ureta, 2003; Yang, 2005; Gyimah-Brempong \& Asiedu, 2015), housing (Osili, 2004), entrepreneurship (Ahmed, 2000; Mishra 2005; Sofranko \& Idris, 1999), investment (Manic, 2017; Jena, 2018; Nzima et al., 2016; Castelhano et al., 2016) and poverty alleviation (Cuecuecha \& Adams, 2016; Azam et al., 2016; Akobeng, 2016). The importance of foreign remittances is twofold. First, from the recipient household perspective, the inflow of remittances is seen as an additional source of income intended to boost ordinary consumption besides promoting the family's general welfare. Second, at the macroeconomic level, remittances are expected to stimulate private sector investment particularly in developing countries that are characterized by inefficient financial markets and credit constraints (Wang, 2016; Leon, 2015), bearing in mind that they receive the biggest share of these capital flow. However, since the bulk of remittances are sent through informal channels, banking sector development is viewed as an important link between remittances and private sector investment. It is on this background this study investigates whether banking sector development moderates the relationship between remittances and private sector investment in Sub-Saharan Africa.

\subsection{Statement of the Problem}

Foreign remittances are progressively becoming an important external source of development finance, after foreign direct investment, for the developing and emerging economies (Moniruzzaman, 2016; Williams, 2016; Sobiech, 2019). Conversely, extant literature shows that remittances are predominantly used for consumption, purchase of land and usual household spending, which have little impact, if any, on the economic development of the receiving country (Gebregziabher, 2016; Quartey, 2019; Kassa, 2017). The argument underlying this traditional perspective is that households have no incentive to save and remittances are meant to cushions household against adverse economic situations (Jahjah et al., 2003; Connel \& Conway, 2000). However, recent studies have established that foreign remittances support entrepreneurial undertakings (McCormick \& Wahba 2001; Dustmann \& Kirchkamp, 2002; Woodruff \& Zenteno, 2007) and economic growth (Fayissa \& Nsiah, 2008; Catrinescu et al., 2009), implying that capital flows could stimulate private sector investment if leveraged through financial intermediation. Moreover, researchers claim that foreign remittances thrive in countries with the underdeveloped financial system since these capital transfers; are informal, more stable from economic shocks and that the receiving households can use future receipts as loan collaterals (Inoue, 2018; Chen \& Jayaraman, 2016; Sobiech, 2019). Nevertheless, the relationship between foreign remittances, private sector investments, and banking sector development is unclear. Thus, the purpose of this study is to investigate the effect of foreign remittances on private sector investments and the moderating role of the banking sector development in SubSaharan Africa.

\section{Literature Review and Theoretical Perspective}

\subsection{Foreign Remittances}

Foreign remittances denote certain transactions that are instigated by individuals living and working outside their countries of birth as transfers for their migration. According to the World Bank's Africa Development Indicator (2008), workers' remittances are current transfers by migrant workers and wages and salaries earned by non-resident workers. Workers' remittances are classified as current private transfers from migrant workers who are residents in the host country to recipients in their country of origin. They include only transfers made by workers who have been living in the host country for more than a year, irrespective of their immigration status. Compensation of 
employees is the income of migrants who have lived in the host country for less than a year.

Remittances can be split into three major components; first, the migrants' salaries and wages or other benefits earned by the migrant in the host countries. The second component is the current transfers by migrants who are employed in new economies and are considered residents there. Third, capital transfers that result from the correspondence between the migrants and their households that include; the flow of goods (personal effects) accompanying the migrant, his flow of financial assets and the change in the stock positions due to the change in his residence status.

Studies show that foreign remittances have an enormous effect on the various macro-economic factors of the receiving countries. A study by Aggarwal et al., 2010), which used a sample of 109 emergent economies and panel data for 1975-2003, found that a $1 \%$ growth in remittances initiated a $0.35-0.37 \%$ increase in bank deposits and a $0.29 \%$ increase in domestic credit to the private sector. Brown et al., 2013) study, which focused on Azerbaijan and Kyrgyzstan, revealed that $\$ 1,000$ growth in remittances increased the probability of the receiving household opening a bank account by $0.1 \%$, which emphasizes the relationship between remittances to banking sector development.

Various factors have been cited in extant literature as influencing the direction and the volume of foreign remittances flow: household income, age, gender, education, home country GDP, exchange rate, inflation and marital status (Simpson \& Sparber, 2019; Biyase \& Tregenna, 2016; Panda \& Trivedi, 2015; Tabit \& Moussir, 2016). It is argued that remittances are intended to supplement the receiving households' income and to smoothen their consumption, in the event of large and temporary fluctuations in the economy (Apergis \& Cooray, 2018; Musah-Surugu et al., 2018). Macro-economic studies show that remittances have a long-run impact on the receiving country's macroeconomic factors, though; the validity of this assertion depends on whether these transfers are allocated to consumption or private investment (Docquier \& Rapoport, 2005). Durand et al., (1996) claim that remittances influence a country's economy directly either through investment or indirectly from the multiplier effect of consumption, which elicits investments in the production of goods and services to meet the increased demand. Yet, studies claim that remittances support entrepreneurship and new venture creation (Yang, 2004, Amuedo-Dorantes \& Pozo, 2006). Besides, remittances have been cited as a source of seed capital to approximately $2 / 3$ of new startups (Kapur, 2005; Hansing \& Orozco, 2014; Vaaler, 2011). Further, researchers claim that migrant's savings sent back home during his/her stay in the host country would ignite the urge for self-employment upon return (Dustmann, 2001; Ilahi, 1999; Mesnard, 2004).

\subsection{Foreign Remittances and Private Sector Investment}

Private sector investment is the key engine for economic growth, job creation and complements public sector investment (Santandrea et al., 2015; Ade et al., 2017; Park et al., 2016; McEwan et al., 2017). Private sector investment is associated with a high level of employment, increased foreign direct investment, economic growth, poverty alleviation and high per capita income (Haroon \& Nasr, 2011; Nwakoby \& Bernard, 2016; Obayori et al., 2018). Owing to its significance in stimulating economic growth and the wellbeing of the populaces, researchers have engrossed their work on the most important determinants of private investment. Wang et al. (2018), Wang et al., (2019), and Szczygielski et al., 2017) argue that public sector investment is an important ingredient for private sector investment. Nevertheless, non-infrastructural public investment would crowd out the level of private sector involvement in economic development (Geddes et al., 2017; Idris \& Bakar, 2017). Studies by Valadkhani (2004) and Khan \& Rinluhart (1990), singled out factors such as GDP growth rate, household level of income, the balance of payment and inflation rate as key determinants of private sector investment. However, financial constraint stands out as the key hindrance to private sector investment in developing and emerging economies (Park et al., 2016; Obafemi et al., 2015; Ugwu et al., 2017).

Previous studies have examined how household allocates remittances between consumption and investment. However, most of the existing studies favor the single model usage of remittances; remittances are either used for consumption or investment. Studies have also revealed that households allocated only a small portion, if any, of the transfers to investment (Hossain \& Hasanuzzaman, 2013; Hall, 2007). Citing examples of Uganda and Pakistan, Stark (1980) observed that migrants' households tended to invest more in capital intensive agriculture. Correspondingly, a study by Oberai, and Singh (1980), in Punjab, found that the receiving households spend approximately $75 \%$ of the foreign remittances on consumption and only $6.1 \%$ on productive investment. To add, studies have also revealed that rural households who happen to be the major recipients of remittances maintain that the households tend to spend the remittances on luxuries and durable goods to catch up with their urban counterparts (Olowa, \& Awoyemi, 2011; Latif \& Ashfaq, 2013). Arguably, it is undeniable fact that a fair share of foreign remittances is apportioned to consumption.

The relationship between remittances and investment 
was investigated by Durand et al., (1996) in Mexico. The study concluded that only $10 \%$ of remittances were spent on productive investments. Further, the study found that $14 \%$ was spent on housing, and the rest of $76 \%$ was spent on consumption. The author further observed that lack of access to financial markets prompted rural households to invest remittances in locally available opportunities such as land, housing, and educations. In the same line, a study by Adams (1998), which focused on Egypt and Pakistani, found that remittances receiving households spent much of these foreign cash flows on land and housing besides they have a higher marginal propensity to save compared to nonreceiving households. From a different perspective, Acharya and Leon-Gonzalez (2018), Azam and Raza (2016) and Bouoiyour and Miftah (2016) contend that households may opt to spend foreign remittances on human capital and related opportunity with a greater potential for future income. Several studies have linked foreign remittances to higher school retention rates (Pilařová \& Kandakov, 2017; Kumar, 2019; Edward \& Ureta, 2003).

The existence of social ties between the migrant and the household dispels the notion of pure investment motive in remittances (Mahapatro, 2017; Coon \& Neumann, 2015; Azizi, 2017). A striking feature of diaspora investment is the commonality of stimulants with other external capital flows; foreign direct and official development assistance. Though, Olubiyi and Olarinde (2015) stated that "remittances act as 'illicit grease money' used to lubricate the wheels of bad governance and allows poor and perhaps inefficient government policy to strive", implying that the quality of their home country's governance and legal structure may not influence their decision to remit or influence, which is not the case with other external capital flows. From the foregoing literature, it is evident that the relationship between foreign remittances and private sector investment is unclear and requires further investigation. Thus, the hypothesis of this study is as follows:

$\mathbf{H}_{01}$ : Foreign remittances has no significant effect on private sector investment

\subsection{Banking Sector Development, Foreign Remittances and Private Sector Investment}

Banking sector development is the process of improving the quality and quantity of financial product and efficiency in providing financial services to the banking industry in the financial system (Qamruzzaman \& Jianguo, 2018). The banking sector plays a crucial role in economic development by availing requisite credit for private sector investment. Conventionally, banks create loans form deposits received from customers; though banks retain part of the deposits as liquid reserves for precautionary purposes.
Besides, banks act as investment agents and advisers to prospective investors. Therefore, the state of a country's banking sector influences its private sector investment. Though there is an important connection between the banking sector and investment, the banking sectors of developing and emerging economies are largely considered inefficient, which scholars have attributed to the huge variation between the interest on deposits and the lending rate leading to a wide financing gap (Yiheyis \& Woldemariam, 2016).

Amid an underdeveloped banking sector and weak legal institutions, the developing countries receive the largest share of foreign remittances, which, if tapped and leveraged through the banking sector, could bridge the financing gap and ultimately improve private sector investment (Hamdar \& Nouayhid, 2017; Stojanov et al., 2019). Moreover, foreign remittances are believed to have a more pronounced impact in countries characterized by underdeveloped financial markets (Ramirez \& Sharma, 2008; Adams \& Klobodu, 2016). Therefore, it is also arguable that remittances substitute for underdeveloped financial markets through easing credit constraints. Further, the banking sector can attract more remittances through incentives such as agent banking, advancing credit against anticipated receipts and provision of free financial advice to households, which have an impact on private sector investment (Freud \& Spatafora 2008). Some researchers also claim that foreign remittances support banking sector development. A study by Demirgüç-Kunt et al. (2011) in Mexico found that $1 \%$ increase in the number of remittances receiving household led to a $0.16 \%$ change in the number of bank branches, a $25 \%$ increase in the number of bank accounts and a $2.5 \%$ points in the deposit/GDP ratio. A similar conclusion was made by Olaniyan (2019), Ambrosius and Cuecuecha (2016) and Fowowe and Ibrahim (2016). Deductively, this viewpoint suggests that foreign remittances are strongly associated with the growth of the banking sector, implying that households can spend these transfers in the acquisitions of durable goods or other long-term investments. Therefore, the study postulates as follows:

$\mathbf{H}_{\mathbf{0 2}}$ : Banking sector development does not significantly moderate the relationship between foreign remittance and private sector investments

\subsection{Theoretical Perspective}

This study is grounded in the modern portfolio and financial intermediation theories. The relationship between foreign remittances and private sector investment is best explained by the portfolio theory advanced by Harry Markowitz (1952) in his seminal paper "Portfolio 
Selection". The Modern Portfolio Theory (MPT) is generally a framework used for generating and choosing a list of feasible portfolios of financial assets grounded on the expected returns on prospective investment opportunities and investor risk orientation. This framework is commonly christened as the mean-variance analysis, which is currently an important principle in the field of investment and securities analysis. Conservative wisdom has continually warned of not putting all the eggs in one basket; this maxim emphasizes the importance of risk diversification. This theory maintains that assets whose returns are highly correlated may all collapse concomitantly because if one single investment gets ruined the same could happen to the other bunch of investments due to their high degree of association. Portfolio theory cautions that allocating all the monies in investments is imprudent no matter how inconsequential the chance is that any one single investment will fail to materialize.

The major postulation of this theory is that migrants acquire assets and save their income for reasons similar to those of the non-migrants. However, the migrant's investment decisions are comparatively different from those of the non-migrants in the sense that migrants have the advantage of acquiring assets in two countries, i.e. the host country where he resides and back in his home country. A study by Amuedo-Dorantes and Pozo (2010), asserts that migrants' decisions to remit are not solely driven by altruism, as argued by many scholars, but also a self-driven motive of investing savings and other gains back home as a strategy to diversify risks and in preparation of their return. The study further maintains that remittances will vary in response to movements in portfolio variables, such as exchange rate, per capita income, interest rate differentials, and political risk, signifying that migrants fine-tune their portfolio of assets at home and in the host country to take advantage of changing economic opportunities in the two countries.

Studies show that portfolio variables seem to influence the remittances investment behavior of the immigrants originating from the poorer countries much more than those from the developed countries. This observation suggests that investing in assets is a risk diversification and consumption smoothing strategy available for migrants whose home country is characterized by a low cost of living as compared to the host country. In most cases, the migrants are in a better position to assist their families back home during harsh economic periods through remittances and other transfers; however, the migrants' families residing in the home country are likely to be limited in their financial capability to cater for the living expenses of the migrant in the foreign country. Therefore, as a way to caution them against this uncertainty, the migrants will device saving schemes that shield them against possible income risks. The immigrants can use several strategies such as the accumulation of physical assets and securities in the two countries while trading off his portfolio holding in response to prevailing macro-economic conditions in the two countries.

Financial intermediation theories are built around the assumptions of efficient capital markets; intermediaries serve to reduce transaction costs and informational asymmetries (Scholtens \& Van, 2003). Presently, theories on investment are modeled around the role of financial and non-financial institutions as catalysts of investment. The earliest proponent of financial intermediation was Schumpeter (1932) who pointed out the role of financial institutions in promoting technology advancement. Later on, Keynes conjectured that the state of credit in an economy determines the level of investment. Moreover, a study by Gurley and Shaw (1973) found that the absence of financial intermediation affected self-financing and that economic growth. Moreover, banking institutions support investment by availing financial resources since they bridge information asymmetry between capital owners and investors. In the context of remittances flow, migrants may opt to invest since these flows take place in the context of information asymmetry. Essentially, altruism is the key motive for sending remittances. However, information imperfection between the migrant and the household on the household's consumption behaviours and the amount of remittances to be sent may prompt the migrant to support the family in starting income-generating activities back home.

In absence of generosity, the migrant is guided by selfinterest and is predisposed to investing back home. After a decision has been made to invest back home, the migrant can elect to invest directly or through his family members. However, due to the distances between him and his agents back home, agency problems may develop, prompting him to invest directly in stock markets where the cost of monitoring is minimal. Additionally, remittances are usually received in a lump sum, and the household may decide to keep in a bank for future use. One of the operational strategies of commercial banks is to receive deposits in the short term and lend in long-term, thus making it a risky venture. This would, therefore, force the remittances receiving household to save part of the remittances in saving accounts, which are more liquid, for precautionary purposes.

\section{Research Design}

A research design is a plan that specifies the methods and procedures for data collection and analysis for purposes of answering a research question. It provides a framework for 
the collection, measurement, and analysis of data. The study was guided by explanatory research design which seeks to establish the causal relationship between variables.

\subsection{Target Population and Dataset}

The research focused on Sub-Saharan Africa countries. However, due to the incompleteness of data, only fifteen (15) countries qualified for analysis. Panel data was extracted from the Africa Development Indicator Database, published and maintained by the World Bank, for the years 1986-2017, which totaled to 480-year observations.

\subsection{Research Empirical Model}

The relationship between variables was examined through hierarchical regression equations as shown below.

Step 1: Testing the effect of the control variables on the dependent variable. At this stage, private sector investment was regressed on GDP growth, FDI inflow, exchange rate, and trade openness.

$\mathrm{PSI}_{\mathrm{it}}=\beta_{0}+\beta_{1} \mathrm{GDP}_{\mathrm{it}}+\beta_{2} \mathrm{FDI}_{\mathrm{it}}+\beta_{3} \mathrm{EXR}_{\mathrm{it}}+\underset{\mathrm{Model}(1)}{\beta_{4} \mathrm{TO}_{\mathrm{it}}+}$

Step 2: Testing the effect of the predictor variable on the dependent variable. The equation is shown below.

$\mathrm{PSI}_{\mathrm{it}}=\beta_{0}+\beta_{1} \mathrm{GDP}_{\mathrm{it}}+\beta_{2} \mathrm{FDI}_{\mathrm{it}}+\beta_{3} \mathrm{EXR}_{\mathrm{it}}+\beta_{4} \mathrm{TO}_{\mathrm{it}}+\beta_{5} \mathrm{FREM}_{\mathrm{it}}$

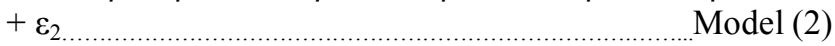

Step 3: Testing the effect of the predictor variable and the moderator on the dependent variable. The regression model is depicted as;

$\operatorname{PSI}_{\text {it }}=\beta_{0}+\beta_{1} \mathrm{GDP}_{\mathrm{it}}+\beta_{2} \mathrm{FDI}_{\mathrm{it}}+\beta_{3} \mathrm{EXR}_{\mathrm{it}}+\beta_{4} \mathrm{TO}_{\mathrm{it}}+$

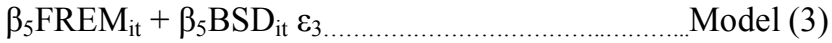

Step 4: Testing for moderation by introducing an interaction term, the product of the predictor variable (remittances) and the moderator (banking sector development), in the model.

$\mathrm{PSI}_{\mathrm{it}}=\beta_{0}+\beta_{1} \mathrm{GDP}_{\mathrm{it}}+\beta_{2} \mathrm{FDI}_{\mathrm{it}}+\beta_{3} \mathrm{EXR}_{\mathrm{it}}+\beta_{4} \mathrm{TO}_{\mathrm{it}}+\beta_{5} \mathrm{REM}_{\mathrm{it}}$

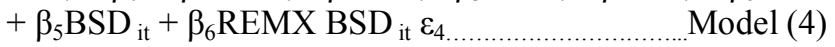
Where,

PSI $=$ Private Sector Investment

FREM $=$ Foreign Remittances

$\mathrm{BSD}=$ Banking Sector Development

GDP $=$ Gross Domestic Product Annual Growth

$\mathrm{TO}=$ Trade Openness

FDI=Foreign Direct Investment Inflow

$\mathrm{EXR}=$ Exchange Rate

$\varepsilon=$ error term

\subsection{Measurement of Variables}

Research variables must be measurable for the hypothesis to be tested. The study had six variables: private sector investment (outcome variable), remittances (predictor variable), banking sector development (moderator) and four control variables (GDP growth rate, FDI inflow, exchange rate, and trade openness). These variables were measured as discussed in the next section.

\subsubsection{Private Sector Investment}

This is the dependent variable in the study. Private sector investment is the share of a country's capital formation attributed to private citizens or the value of a country's total assets owned by its citizens. The proxy for this variable is the gross fixed capital formation (private sector) $\%$ of GDP as defined by the World Bank. This measure was used in previous studies (Nwakoby \& Bernard, 2016; Marang' a et al., 2018; Pickson \& Ofori-Abebrese, 2016).

\subsubsection{Foreign Remittance}

Foreign remittances will be taken as the figure given by the World Bank Indicator. World Bank (2008) defines remittances as "Workers' remittances and compensation of employees comprise current transfers by migrant workers and wages and salaries earned by non-resident workers. Workers' remittances are classified as current private transfers from migrant workers who are residents of the host country to recipients in their country of origin. They include only transfers made by workers who have been living in the host countries for more than a year, irrespective of their immigration status. Compensation of employees is the income of migrants who have lived in the host country for less than a year. This may include the migrant's salaries and wages or other benefits earned by the migrant in the host country". The variable is standardized as a ratio of GDP (Remittances/GDP) to take into consideration the variation in the size of the countries under study.

\subsubsection{Banking Sector Development}

In this study banking sector development is the moderator and it is measured as domestic credit to the private sector; which are claims on the private sectors by commercial banks in the form of loan advances. Domestic credit is the aggregate of liquid liabilities of financial systems and other claims on the private sector by the banking sector as a percentage of GDP. This is a standard measure of banking sector development (Ahmed \& Bashir, 2016; Low et al., 2018; Bayar et al., 2018; Habibullah et al., 2017). This data is available in the World Bank Development Indicator, the International Financial Statistics, and IMF databases. 


\subsubsection{Control Variables}

Several control variables were incorporated into the econometric model to reduce the probability of a spurious relationship between the dependent variable, the independent variable, and the moderator. The first of these is economic growth, where it is hypothesized that the willingness of the diaspora to invest back home depends on the home country's rate of economic growth. Admittedly, growth stimulates demand for products, and the private sector responds to this demand by expanding their production, which calls for additional investments in capital equipment. Accordingly, this variable is controlled by the Gross Domestic Product Growth (Bonga \& Nyoni, 2017). Second, the exchange rate influences an investor's preference for certain assets, which could call for a reorganization of his portfolios (Binding \& Dibiasi, 2017; Baltar et al., 2016). This may lead to increasing the level of investment in the home country by remitting more or holding more assets in the host country by remitting less. The proxy for this variable is the annual local currency/US\$(LCU US\$). Third, trade openness offers a platform for migrants to invest in the diaspora and back home, and it is hypothesized to have a significant positive effect on financial development. The study measured trade openness as the ratio of exports to GDP (Arif et al., 2017; Kaushal \& Pathak, 2015; Hye \& Lau, 2015). Fourth, credit constraint is a major hindrance to private sector investment, particularly in developing countries. This variable was measured as the country's annual average lending rate.

\subsection{Data analysis}

The data was analyzed through descriptive and inferential statistics. Specifically, the data was summarized using the mean, minimum and maximum value and standard deviation. Pairwise correlation analysis was used to establish the magnitude and the nature of the relationship between the research variables. Hierarchical multiple regression was used to test the hypothesis (Hayes, 2017). The choice between fixed effect and random effect regression analysis was based on the results of the Hausman test; the results for each of the tests are presented in table 6 .

\section{Results}

\subsection{Panel Data Diagnostic Tests}

Before subjecting the data to multiple regression analysis and other panel diagnostic tests, the data was transformed through the first differencing, $\mathrm{Y}_{\mathrm{t}}-\mathrm{Y}_{\mathrm{t}-1}$, to ensure that it was stationary. Other diagnostic tests conducted included multicollinearity and autocorrelation. The results of the robustness tests, presented in Tables 1-3, allowed for further statistical analysis.

Table 1: Unit Root Tests

\begin{tabular}{|c|c|c|c|}
\hline Variable & Breitung & Fisher-ADF & Im-Pesaran-Shin \\
\hline $\begin{array}{c}\text { Private Sector I } \\
\text { nvestment }\end{array}$ & $-4.69(0.00)$ & $45.28(0.00)$ & $-3.64(0.00)$ \\
\hline $\begin{array}{c}\text { Foreign Remitt } \\
\text { ances }\end{array}$ & $-6.33(0.00)$ & $45.27(0.00)$ & $-3.51(0.00)$ \\
\hline $\begin{array}{c}\text { Banking Sector } \\
\text { Development }\end{array}$ & $-5.86(0.00)$ & $40.07(0.00)$ & $-2.2445(0.01)$ \\
\hline $\begin{array}{c}\text { GDP Annual gr } \\
\text { owth rate }\end{array}$ & $-4.15(0.00)$ & $84.91(0.00)$ & $-5.26(0.00)$ \\
\hline Exchange Rate & $-8.45(0.00)$ & $24.36(0.00)$ & $-1.807(0.04)$ \\
\hline FDI inflow & $-5.77(0.00)$ & $77.13(0.00)$ & $-3.82(0.00)$ \\
\hline Trade Openness & $-5.81(0.00)$ & $44.63(0.00)$ & $3.69(0.00)$ \\
\hline
\end{tabular}

Table 2: Results of Multicollinearity Test

\begin{tabular}{|c|c|c|}
\hline Variable & VIF & 1/VIF \\
\hline FDI Inflow & 1.13 & 0.886331 \\
\hline Exchange Rate & 1.11 & 0.901513 \\
\hline Trade Openness & 1.05 & 0.949623 \\
\hline Foreign Remittances & 1.03 & 0.966453 \\
\hline GDP Growth & 1.03 & 0.966562 \\
\hline Banking Sector Development & 1.01 & 0.988397 \\
\hline Mean VIF & $\mathbf{1 . 0 6}$ & \\
\hline
\end{tabular}

Table 3: Results of the Autocorrelation Test

\begin{tabular}{|c|c|c|c|c|}
\hline \multicolumn{5}{|c|}{ White's test for Ho: homoscedasticity } \\
\hline Ha: unrestrictec & ieterosce & ity: & ) $=5.90$ & Prob $>$ chi $2=0.3164$ \\
\hline \multicolumn{5}{|c|}{ Cameron \& Trivedi's decomposition of IM-test } \\
\hline Source & chi2 & df & $\mathbf{p}$ & \\
\hline $\begin{array}{l}\text { Heteroskeda } \\
\text { sticity }\end{array}$ & 5.90 & 5 & 0.3164 & \\
\hline Skewness & 4.53 & 2 & 0.1036 & \\
\hline Kurtosis & 3.00 & 1 & 0.0832 & \\
\hline Total & 13.43 & 8 & 0.0978 & \\
\hline
\end{tabular}

\subsection{Descriptive and Inferential Statistics}

Table 4 presents the descriptive statistics of the rese arch variables. The table shows that the mean private sector investment in Sub-Saharan Africa, for the period 2008-2017, was $13.666 \%$ of GDP. Further, the avera ge foreign remittance was $6.47 \%$ of GDP, while the $\mathrm{m}$ ean banking sector development was $28.34 \%$ of GDP. Additionally, the table shows that the average annual GDP growth rate in the region was $1.35 \%$; whereas, th e mean exchange rate (USD) was approximately 237.82 . The average FDI inflow and trade openness in Sub-Sa haran Africa was $2.56 \%$ and $33.84 \%$ of GDP, respecti vely. 
The results of the pairwise correlation are shown in Table 5. Based on the results as displayed in the table, private sector investment had a positive and significant correlation with the following variables: foreign remittances $(\mathrm{r}=0.4730$, $\rho<0.01$ ), banking sector development $(\mathrm{r}=0.0898, \rho<0.01)$, GDP growth $(\mathrm{r}=0.1305, \rho<0.01)$, FDI $(\mathrm{r}=0.3512, \rho<0.01)$, and trade openness $(\mathrm{r}=0.1412, \quad \rho<0.01)$, though its correlations with exchange rate was negative $(-0.1587)$. Besides, the tables indicate that foreign remittance and banking sector development had a negative correlation While foreign remittances and FDI were positively correlated $(r=0.1641, \rho<0.01)$, which suggests the complementariness of these capital flows. Besides, the banking sector development had a negative correlation with foreign remittances $(\mathrm{r}=-0.1098, \rho<0.01)$, FDI $(\mathrm{r}=-0.1103$, $\rho<0.01)$ and trade openness $(r=-0.0845, \rho<0.01)$, which confirms that external capital flow thrives in weak and inefficient financial systems.

Table 4: Summary of Descriptive Statistics

\begin{tabular}{|c|c|c|c|c|c|}
\hline Variable & Obs & Mean & Std. Dev. & Min & Max \\
\hline $\begin{array}{c}\text { Private sector } \\
\text { investment } \\
\text { /GDP }\end{array}$ & 480 & 13.6667 & 7.564802 & 0.0797196 & 53.18923 \\
\hline $\begin{array}{c}\text { Foreign } \\
\text { Remittances } \\
\text { /GDP }\end{array}$ & 480 & 6.470789 & 16.05456 & 0.0004344 & 106.4789 \\
\hline $\begin{array}{c}\text { Banking } \\
\text { Sector } \\
\text { Development }\end{array}$ & 480 & 28.33857 & 28.14529 & 1.542268 & 167.536 \\
\hline $\begin{array}{c}\text { GDP Annual } \\
\text { growth rate }\end{array}$ & 480 & 1.352016 & 4.426739 & -18.58049 & 20.72159 \\
\hline $\begin{array}{c}\text { Exchange } \\
\text { Rate (USD) }\end{array}$ & 480 & 237.8185 & 470.3499 & 0.0002749 & 3978.088 \\
\hline $\begin{array}{c}\text { FDI inflow } \\
\text { /GDP }\end{array}$ & 480 & 2.556259 & 4.845204 & -28.62426 & 35.23495 \\
\hline $\begin{array}{c}\text { Trade } \\
\text { Openness }\end{array}$ & 480 & 33.9432 & 18.47651 & 3.212225 & 100.949 \\
\hline
\end{tabular}

Table 5: Correlation Matrix

\begin{tabular}{|c|c|c|c|c|c|c|c|}
\hline Variable & PSD & REM & BSD & GDP & EXCH & FDI & TO \\
\hline Private Sector Investment & 1.0000 & & & & & & \\
\hline Foreign Remittances & $0.4730^{*}$ & 1.0000 & & & & & \\
\hline Banking Sector Development & $0.0898^{*}$ & $-0.1098^{*}$ & 1.0000 & & & & \\
\hline GDP Growth & $0.1305^{*}$ & 0.0741 & -0.0023 & 1.0000 & & & \\
\hline Exchange Rate & $-0.1587^{*}$ & $-0.1496^{*}$ & $-0.2792^{*}$ & -0.0142 & 1.0000 & & \\
\hline FDI Inflow & $0.3512^{*}$ & $0.1641^{*}$ & $-0.1103^{*}$ & $0.1531^{*}$ & 0.0757 & 1.0000 & \\
\hline Trade Openness & $0.1412^{*}$ & -0.0432 & -0.0845 & $0.1834^{*}$ & -0.0218 & $0.3231^{*}$ & 1.0000 \\
\hline
\end{tabular}

\subsection{Regression Results and Hypothesis Testing}

The study had two hypotheses which were stated above: $\mathrm{H}_{01}$ : foreign remittances has no significant effect on private sector investment; $\mathrm{H}_{02}$ : Banking sector development does not significantly moderate the relationship between foreign remittances and private sector development.

The above hypotheses were tested using the results of hierarchical multiple regression presented in Table 6 . The regression results of the dependent variable and the control variables are presented in Model 1. Model 2 illustrates the results of the regression of private sector investment on foreign remittances and the control variables. Model 3 presents the results of the regression of private sector investment on foreign remittances, the control variables and the moderator (banking sector development). Model 4 shows the results of moderation; regression of the dependent variable, the predictor variable, the moderator, the control variables and the interaction term.

Based on the findings presented in Model 1, GDP annual growth $(\beta=0.103, \rho<0.05)$, FDI $(\beta=0.330, \rho<0.05)$ and trade openness $(\beta=0.094, \rho<0.05)$ had a positive and significant effect on private sector investment, implying that they are key determinants of private sector investment.
Conversely, the exchange rate had a negative effect on private sector investment $(\beta=-0.002, \rho<0.05)$, inferring that exchange rate volatility reduces private sector investment. The findings shown in Model 2 indicate that foreign remittances had a positive and significant effect on private sector investment $(\beta=0.362, \rho<0.05)$, thus the null hypothesis, $\mathrm{H}_{01}$ : Foreign remittances has no significant effect on private sector investment, was rejected. The model predicts that a unit change in foreign remittances led to 0.362 units change in private sector development. Similarly, Model 3 shows that banking sector development had a positive and statistically significant effect on private sector development ( $\beta=0.098, \rho<0.05$ ). The second hypothesis; $\mathrm{H}_{01}$ : Foreign remittances has no significant effect on private sector investment, was tested based on the regression results presented in Model 3 and Model 4 as shown in table 6. In Model 3, both foreign remittances $(\beta=0.354, \rho<0.05)$ and banking sector development $(\beta=0.098, \rho<0.05)$ had a positive and significant effect on private sector investment. After introducing the interaction term in Model 4, the interaction term $(\beta=-0.017, \rho<0.05)$, foreign remittances $(\beta=0.346, \rho<0.05)$ and banking sector development $(\beta=$ $0.097, \rho<0.05)$, had a significant effect on private sector 
investment. The negative beta coefficient of the interaction term indicates a "buffering interaction", where an improvement in the banking sector development weakens the effect of foreign remittances on private sector investment. These findings are consistent with the school of thought that postulates that remittances substitute for sound financial development (Inoue, 2018; Abida \& Sghaier, 2014); implying that the impact of foreign remittance on private investment is more pronounced in economies characterized by the inefficient banking sector.

Table 6: Results of Regression Analysis

\begin{tabular}{|l|l|l|l|l|}
\hline & \multicolumn{1}{|c|}{ Model1 } & \multicolumn{1}{|c|}{ Model2 } & \multicolumn{1}{|c|}{ Model3 } & \multicolumn{1}{|c|}{ Model4 } \\
\hline GDPGrowth(\%) & $0.103(3.34)^{* *}$ & $0.098(3.22)^{* *}$ & $0.106(3.49)^{* *}$ & $0.106(3.49)^{* *}$ \\
\hline FDI Inflow/GDP & $0.330(6.02)^{* *}$ & $0.308(5.71)^{* *}$ & $0.303(5.65)^{* *}$ & $0.300(5.59)^{* *}$ \\
\hline Trade Openness/GDP & $0.094(3.53)^{* *}$ & $0.080(2.99)^{* *}$ & $0.080(3.02)^{* *}$ & $0.079(3.00)^{* *}$ \\
\hline Exchange Rate(USD) & $-0.002(-075)^{* *}$ & $-0.002(-2.97)^{* *}$ & $-0.002(-2.99)^{* *}$ & $-0.002(-3.0)^{* *}$ \\
\hline Foreign Rem/GDP & & $0.362(4.35)^{* *}$ & $0.354(428)^{* *}$ & $0.346(4.5)^{* *}$ \\
\hline Banking Sector Dev & & & $0.098(2.79)^{* *}$ & $0.097(2.75)^{* *}$ \\
\hline ForeignRemxBSD & & & & $-0.017(-0.63)^{* *}$ \\
\hline cons & $0.101(1.05)$ & $0.1330(1.41)$ & $0.093(0.98)$ & $0.094(0.99)$ \\
\hline Hausman test chi2 & $0.52(0.9712)$ & $0.99(0.9632)$ & $1.98(0.9214)$ & $2.14(0.9516)$ \\
\hline Rsquared & 0.1654 & 0.1990 & 0.2143 & 0.2148 \\
\hline$\Delta$ R squared & - & 0.0336 & 0.0153 & 0.0005 \\
\hline Chi-square & 92.78 & 115.29 & 124.76 & 124.99 \\
\hline Prob $>$ chi2 & 0.0000 & 0.0000 & 0.0000 & \\
\hline No. of Obs & 465 & 465 & 465 & 15 \\
\hline Number of countries & 15 & 15 & & 4600 \\
\hline
\end{tabular}

\section{Conclusions and Recommendations}

In the last three decades, foreign remittances have grown rapidly to form a significant component of foreign capital inflows to developing and emerging economies; though their banking sector is largely regarded as underdeveloped. In response to the increased flow of remittances, a good number of studies have been done to investigate the effect of foreign remittances on household consumption and other socio-economic dimensions. However, very limited work has been devoted to examine the relationship between foreign remittances, private investment, and banking sector development in Sub-Saharan Africa. Thus, this study sought to investigate the effect of foreign remittances on private sector investment and the moderating role of banking sector development in Sub-Saharan Africa. Based on data drawn from fifteen countries for the period from 1986 to 2017, the study found both foreign remittances and banking sector development had a significant effect on private sector investment. Further, the findings showed that banking sector development significantly moderated the foreign remittances and private investment causality.

Due to the antagonistic interaction between banking sector development and foreign remittances, the study recommends that the remittances receiving countries should find alternative ways of attracting and channeling foreign remittances to development; which can lessen the overreliance on foreign aid, external debt and heavy domestic borrowing. Some of the policy interventions include; issuance of diaspora bonds through private-public partnerships, the creation of mutual funds and appealing for direct investment by citizens working abroad. Besides, the government should create a favorable institutional environment that attracts and channels remittances into investment.

\section{References}

Abida, Z., \& Sghaier, I. M. (2014). Remittances, Finan cial Development and Economic Growth: The Case of North African Countries. Romanian Economic $J$ ournal, 17(51), 137-170.

Acharya, C. P., \& Leon-Gonzalez, R. (2018). Remittanc es, Human Capital, and Economic Growth: Panel Data Evidence from Asia and Sub-Saharan Afric $a$ (No. 18-01). National Graduate Institute for Polic y Studies.

Adams Jr, R. H. (1991). The economic uses and impa ct of international remittances in rural Egypt. Econ omic Development and Cultural Change, 39(4), 695 -722 .

Adams Jr, R. H. (1998). Remittances, investment, and rural asset accumulation in Pakistan. Economic Dev elopment and Cultural Change, 47(1), 155-173.

Adams, R., Lopez-Feldman, A., Mora, J., Taylor, J. E., 
DeWind, J., \& Holdaway, J. (2008). Remittances, inequality and poverty: Evidence from rural Mexi co. Migration and development within and across $b$ orders: Research and policy perspectives on intern al and international migration, 101-130.

Adams, S., \& Klobodu, E. K. M. (2016). Remittances, regime durability and economic growth in Sub-Sa haran Africa (SSA). Economic Analysis and Polic $y, 50,1-8$

Ade, S. M., Chua, S. Y., \& Normee, C. S. C. (2017). The relationship between public and private sector investments in Syria. Aestimatio: The IEB Internat ional Journal of Finance, 14, 76-89.

Aggarwal, R., Demirguc-Kunt, A., \& Martinez Peria, M. S. (2006). Do workers' remittances promote fina ncial development? The World Bank.

Ahmed, I. I. (2000). Remittances and their economic i mpact in post-war Somaliland. Disasters, 24(4), 380 -389 .

Ahmed, J., \& Bashir, M. F. (2016). An empirical inves tigation of banking sector development and econom ic growth in a panel of selected SAARC countrie s. Theoretical and Applied Economics, 23(2), 65-72

Akobeng, E. (2016). Out of inequality and poverty: Ev idence for the effectiveness of remittances in SubSaharan Africa. The quarterly review of economics and finance, 60, 207-223.

Ambrosius, C., \& Cuecuecha, A. (2016). Remittances a nd the use of formal and informal financial service s. World Development, $77,80-98$

Amuedo-Dorantes, C., \& Pozo, S. (2006). Migration, r emittances, and male and female employment patte rns. American Economic Review, 96(2), 222-226.

Amuedo-Dorantes, C., \& Pozo, S. (2010). Remittances and their response to portfolio variables (No. 102 1). Centre for Research and Analysis of Migration (CReAM), Department of Economics, University College London.

Apergis, N., \& Cooray, A. (2018). Asymmetric real ex change rates and poverty: The role of remittance s. Emerging Markets Review, 35, 111-119.

Arif, I., Kazmi, S. W., \& Khan, L. (2017). Relationshi $\mathrm{p}$ between trade openness and energy consumption in oil importing Asian countries. Journal of Finan ce \& Economics Research, 2(1), 37-53.

Azam, M., \& Raza, S. A. (2016). Do workers' remitta nces boost human capital development. Pakistan De velopment Review, 55(2), 123-150.

Azam, M., Haseeb, M., \& Samsudin, S. (2016). The i mpact of foreign remittances on poverty alleviation: Global evidence. Economics \& Sociology, 9(1), 26 4.

Azam, M., Shahbaz, M., Kyophilavong, P., \& Abbas,
Q. (2016). External sources and economic growth-t he role of foreign remittances: Evidence from Euro pe and Central Asia. The Journal of Developing Ar eas, 50(2), 367-387

Azizi, S. (2017). Altruism: primary motivation of remit tances. Applied Economics Letters, 24(17), 1218-122 1.

Baltar, C. T., Hiratuka, C., \& Lima, G. T. (2016). Rea 1 exchange rate and investment in the Brazilian ma nufacturing industry. Journal of Economic Studies, 4 3(2), 288-308.

Bayar, Y., Gavriletea, M., \& Ucar, Z. (2018). Financial Sector Development, Openness, and Entrepreneurs hip: Panel Regression Analysis. Sustainability, 10(1 0), 3493.

Binding, G., \& Dibiasi, A. (2017). Exchange rate unce rtainty and firm investment plans evidence from $\mathrm{S}$ wiss survey data. Journal of Macroeconomics, 51, 1 -27. Biyase, M., \& Tregenna, F. (2016). Determina nts of remittances in South Africa (No. 176). South ern Africa Labour and Development Research Unit, University of Cape Town

Bonga, W. G., \& Nyoni, T. (2017). An empirical analy sis of the determinants of private investment in $\mathrm{Zi}$ mbabwe. Dynamic Research Journals' Journal of E conomics \& Finance (DRJ-JEF), 2(4), 38-54.

Bouoiyour, J., \& Miftah, A. (2016). The impact of re mittances on children's human capital accumulation: Evidence from Morocco. Journal of International Development, 28(2), 266-280

Brown, R. P., Carmignani, F., \& Fayad, G. (2013). Mi grants' remittances and financial development: Mac ro-and micro-level evidence of a perverse relations hip. The World Economy, 36(5), 636-660.

Buch, M., Anja, K., \& Marie-Helene, L. (2002). Work er Remittances and Capital Flows. Kiel Working $P$ aper No. 1130

Castelhano, M., Lawell, C. Y. C. L., Sumner, D. A., \& Taylor, J. E. (2016). The effects of migration a nd remittances on productive investment in rural Mexico. Working Paper

Catrinescu, N., Leon-Ledesma, M., Piracha, M., \& Quil lin, B. (2009). Remittances, institutions, and econo mic growth. World Development, 37(1), 81-92

Chami, R., Ernst, E., Fullenkamp, C., \& Oeking, A. (2 018). Are Remittances Good for Labor Markets in LICs, MICs and Fragile States? Evidence from C ross-Country Data. International Monetary Fund. $W$ P/18/102.

Chen, H., \& Jayaraman, T. (2016). Role of financial s ector in the remittances-growth nexus in Fiji. Remit tances Review, 1(1), 17-36.

Connell, J., \& Conway, D. (2000). Migration and remit 
tances in island microstates: a comparative perspect ive on the South Pacific and the Caribbean. Interna tional journal of urban and regional research, 24 (1), 52-78.

Coon, M., \& Neumann, R. (2015). Follow the Money: Remittance Responses to FDI Inflows. Journal of Globalization and Development, 8(2), 121-126.

Cuecuecha, A., \& Adams, R. J. (2016). Remittances, h ousehold investment and poverty in indonesia. Jour nal of Finance and Economics, 4(3), 12-31

Demirgüç-Kunt, A., Córdova, E. L., Pería, M. S. M., \& Woodruff, C. (2011). Remittances and banking $\mathrm{s}$ ector breadth and depth: Evidence from Mexico. Jo urnal of Development Economics, 95(2), 229-241.

Di Bella, J., Grant, A., Kindornay, S., \& Tissot, S. (2 013). The Private Sector and Development: Key C oncepts. Ottawa: North-South Institute

Docquier, F., \& Rapoport, H. (2005). The economics o f migrants' remittances. Handbook on the Economic $s$ of Altruism, Reciprocity and Giving, forthcoming, North-Holland: Amsterdam.

Durand, J., Kandel, W., Parrado, E. A., \& Massey, D. S. (1996). International migration and development in Mexican communities. Demography, 33(2), 249264.

Dustmann, C. (2001). Why go back? Return motives o f migrant workers. International Migration: Trends, Policies and Economic Impact, Routledge, London, 229-249.

Dustmann, C., \& Kirchkamp, O. (2002). The optimal migration duration and activity choice after re-migr ation. Journal of development economics, 67(2), 351 -372 .

Edwards, A. C., \& Ureta, M. (2003). International mig ration, remittances, and schooling: Evidence from El Salvador. Journal of development economics, 72 (2), 429-461.

Escribà-Folch, A., Meseguer, C., \& Wright, J. (2018). Remittances and protest in dictatorships. American Journal of Political Science, 62(4), 889-904

Fayissa, B., Nsiah, C., \& Tadasse, B. (2008). Impact o $\mathrm{f}$ tourism on economic growth and development in Africa. Tourism Economics, 14(4), 807-818.

Fowowe, B., \& Ibrahim, T. M. (2016). Remittances an d economic development in Lesotho: does financial sector development matter?. Economics Bulletin, 36 (4), 2209-2224.

Gebregziabher, K. G. (2016). The Impact of Internation al Remittances on Expenditure Patterns of Urban Households in Ethiopia. In Poverty and Well-Being in East Africa (pp. 117-137). Springer, Cham.

Geddes, A., Schmidt, T. S., \& Steffen, B. (2018). The multiple roles of state investment banks in low-ca rbon energy finance: An analysis of Australia, the UK and Germany. Energy Policy, 115, 158-170.

Gurley, J. G., \& Edward, S. (1973). Shaw. 1960. Mone $y$ in a Theory of Finance.

Gyimah-Brempong, K., \& Asiedu, E. (2015). Remittanc es and investment in education: Evidence from $\mathrm{Gh}$ ana. The journal of international trade \& economic development, 24(2), 173-200

Habibullah, M. S., Baharom, A. H., Din, B. H., \& Fur uoka, F. (2017). Mitigating shadow economy throu gh dual banking sector development in Malaysia. I n Islamic Economies (pp. 41-62). Palgrave Macmilla n, Cham.

Hall, A. L. (2007). Moving away from poverty: Migra nt remittances, livelihoods, and Development. Movin $g$ out of Poverty, 1, 307-332.

Hamdar, B., \& Nouayhid, S. (2017). Remittances And Foreign Aid As Sources Of External Development Finance: Impacts On Savings And Investment In P ost-War Lebanon. Economia Internazionale/Internati onal Economics, 70(1), 47-72

Hansing, K., \& Orozco, M. (2014). The Role and Imp act of Remittances on Small Business Development during Cuba's Current Economic Reforms.

Hayes, A. F. (2017). Introduction to mediation, moderat ion, and conditional process analysis: A regression -based approach. Guilford Publications.

Hye, Q. M. A., \& Lau, W. Y. (2015). Trade openness and economic growth: empirical evidence from In dia. Journal of Business Economics and Manageme $n t, 16(1), 188-205$.

Hossain, A. N., \& Hasanuzzaman, S. (2013). Remittanc es and investment nexus in Bangladesh: an ARDL bounds testing approach. International Review of Economics, 60(4), 387-407

Idris, M., \& Bakar, R. (2017). Public Sector Spending and Economic Growth in Nigeria: In Search of a Stable Relationship. Asian Research Journal of Arts \& Social Sciences, 3(2), 1-19.

Ilahi, N. (1999). Return migration and occupational cha nge. Review of development economics, 3(2), 170-18 6.

Inoue, T. (2018). Financial development, remittances, a nd poverty reduction: Empirical evidence from a $\mathrm{m}$ acroeconomic viewpoint. Journal of Economics and Business, 96, 59-68.

Inoue, T., \& Hamori, S. (2016). Effects of remittances on poverty reduction in asia. Financial linkages, $r$ emittances, and resource dependence in east asia, 101-117.

Jahjah, M. S., Chami, M. R., \& Fullenkamp, C. (200 3). Are immigrant remittance flows a source of cap ital for development (No. 3-189). International Mon 
etary Fund.

Jena, F. (2018). Migrant remittances and physical inves tment purchases: Evidence from Kenyan household s. The Journal of Development Studies, 54(2), 312-3 26.

Kapur, D. (2005). Remittances: the new development mantra?. Remittances: Development impact and futu re prospects, 331-60.

Kassa, T. M. (2017). Rural youth outmigration, remitta nce and its impacts on migrant-sending households in Gojjam and Wolayta, Ethiopia. Journal of Geog raphy and Regional Planning, 10(4), 57-68.

Kaushal, L. A., \& Pathak, N. (2015). The causal relati onship among economic growth, financial develop ment and trade openness in Indian economy. Intern ational Journal of Economic Perspectives, 9(2), 5-2 2.

Khan, M., \& Rinluhart, C. (1990). Private Sector Deve lopment and Economic Growth in Developing Cou ntries. IMF Staff Papers, 29, 295-320.

Khosa, R. M., \& Kalitanyi, V. (2015). Migration reasons, traits and entrepreneurial motivation of African immigrant entrepreneurs: Towards an entrepreneurial migration progression. Journal of Enterprising Communities: People and Places in the Global Economy, 9(2), 132-155. 